\title{
Phenotype-genotype correlations in Leigh syndrome : new insights from a multicentre study of 96 patients
}

\section{Sofou, Kalliopi}

2018-01

Sofou , K, de Coo , I F M , Ostergaard, E , Isohanni , P , Naess , K, De Meirleir , L, Tzoulis , C , Uusimaa , J , Lönnqvist , T , Bindoff , L A , Tulinius , M \& Darin , N 2018 , '

Phenotype-genotype correlations in Leigh syndrome : new insights from a multicentre study of 96 patients ' , Journal of Medical Genetics , vol. 55 , no. 1 , pp. 21-27 . https://doi.org/10.1136/jmedgenet-2017-10

http://hdl.handle.net/10138/311437

https://doi.org/10.1136/jmedgenet-2017-104891

cc_by_nc

acceptedVersion

Downloaded from Helda, University of Helsinki institutional repository.

This is an electronic reprint of the original article.

This reprint may differ from the original in pagination and typographic detail.

Please cite the original version. 
Phenotype - genotype correlations in Leigh syndrome: New insights from a multicenter study of 96 patients

Kalliopi Sofou ${ }^{1}$, Irenaeus de Coo $^{2}$, Elsebet Østergaard ${ }^{3}$, Pirjo Isohanni ${ }^{4,5}$, Karin Naess $^{6}$, Linda de Meirleir ${ }^{7}$, Charalampos Tzoulis ${ }^{8,9}$, Johanna Uusimaa ${ }^{10,11}$, Tuula Lönnqvist ${ }^{4}$, Laurence A. Bindoff ${ }^{8,9}$, Már Tulinius ${ }^{1}$, Niklas Darin ${ }^{1}$

${ }^{1}$ Department of Pediatrics, The Queen Silvia Children's Hospital, University of Gothenburg, Gothenburg, Sweden

${ }^{2}$ Department of Neurology, Erasmus MC, Rotterdam, The Netherlands

${ }^{3}$ Department of Clinical Genetics, Copenhagen University Hospital Rigshospitalet, Copenhagen, Denmark

${ }^{4}$ Department of Paediatric Neurology, Children's Hospital, University of Helsinki, Helsinki University Hospital, Helsinki, Finland

${ }^{5}$ Research Programs Unit, Molecular Neurology, Biomedicum-Helsinki, University of Helsinki, Helsinki, Finland

${ }^{6}$ Centre for Inherited Metabolic Diseases, Karolinska University Hospital, Stockholm, Sweden

${ }^{7}$ Department of Paediatric Neurology, University Hospital Vrije Universiteit Brussel (VUB), Brussels, Belgium

${ }^{8}$ Department of Neurology, Haukeland University Hospital, Bergen, Norway

${ }^{9}$ Department of Clinical Medicine, University of Bergen, Norway

${ }^{10}$ Institute of Clinical Medicine/Department of Paediatrics, University of Oulu, Oulu, Finland

${ }^{11}$ Medical Research Center, Oulu University Hospital, Oulu, Finland

Correspondence to: Dr. Kalliopi Sofou. Department of Pediatrics, The Queen Silvia Children's Hospital, SE-416 85 Gothenburg, Sweden. Telephone: +46 31 3436416. Fax: +46 31 257960. Email: kalliopi.sofou@vgregion.se.

Word count (main text - revised): 3342

Word count (abstract): 192 


\begin{abstract}
Background: Leigh syndrome is a phenotypically and genetically heterogeneous mitochondrial disorder. While some genetic defects are associated with well-described phenotypes, phenotypegenotype correlations in Leigh syndrome are not fully explored.

Objective: We aimed to identify phenotype-genotype correlations in Leigh syndrome in a large cohort of systematically evaluated patients.

Methods: We studied 96 patients with genetically confirmed Leigh syndrome diagnosed and followed in 8 European centers specializing in mitochondrial diseases.

Results: We found that ataxia, ophthalmoplegia and cardiomyopathy were more prevalent among patients with mitochondrial DNA defects. Patients with mutations in $M T-N D$ and NDUF genes with complex I deficiency shared common phenotypic features, such as early development of central nervous system disease, followed by high occurrence of cardiac and ocular manifestations. The cerebral cortex was affected in patients with NDUF mutations significantly more often than the rest of the cohort. Patients with the m.8993T>G mutation in MT-ATP6 gene had more severe clinical and radiological manifestations and poorer disease outcome compared to patients with the m.8993T $>$ C mutation.
\end{abstract}

Conclusion: Our study provides new insights into phenotype-genotype correlations in Leigh syndrome and particularly in patients with complex I deficiency and with defects in the mitochondrial ATP synthase.

Keywords: Leigh syndrome; mitochondrial DNA; complex I; genetic; MRI 


\section{INTRODUCTION}

Leigh syndrome is an early-onset progressive neurodegenerative disorder, associated with defects of mitochondrial oxidative phosphorylation. It is the most common, distinct phenotype among oxidative phosphorylation disorders in children with an estimated pre-school incidence in western Sweden of 1 per 34,000 births.[1] The disease is typically characterized by subacute onset of psychomotor regression and encephalopathy associated with the development of bilateral symmetrical lesions in the striatum and brainstem, which are the hallmark of the disease.[2] Leigh disease is genetically highly heterogeneous as evidenced by the more than 75 genes, encoded either by the mitochondrial or the nuclear genome, that are implicated in this disorder, with more than one-third of these genes identified in the past 5 years.[3]

Some genotypes causing Leigh syndrome are associated with clear and well-described phenotypic traits, such as cytochrome oxidase deficiency with SURF1 mutations,[6], methylmalonic aciduria with mutations in SUCLA2,[7,8] and biotin-thiamine-responsive basal ganglia disease caused by mutations in the SLC19A3 gene.[9,10] Other genetic defects show weaker correlation with clinical phenotype, particularly as the same mutant protein may result in highly variable clinical presentations and disease outcomes.[11] For example, the m.8993T $>C$ mitochondrial DNA mutation has been associated with a less severe phenotype characterized by later onset and slower disease progression than the m.8993T $>\mathrm{G}$ mutation.[4,12] However, the impact of each of these mutations on survival outcomes and MRI phenotypes has not been investigated.

Mitochondrial respiratory chain disorders and Leigh syndrome in particular, are multisystem disorders. Cardiac involvement is common and occurs in $17-40 \%$ of patients with mitochondrial disease.[13,14] Neonatal or infantile hypertrophic cardiomyopathy has been associated with mutations in NDUFS2,[15] NDUFV2,[16] NDUFA11,[17] NDUFS4,[18] NDUFA2,[19] and ACAD9, [20], and can occur as an isolated finding in nuclear encoded complex I deficiency or in combination with encephalopathy, myopathy and/or lactic acidosis. Biochemical investigations show that complex I deficiency is common in Leigh syndrome, with isolated complex I deficiency found in as many as $37 \%$ in some studies.[2,21,22] Associations between complex I deficiency in Leigh syndrome and disease-specific clinical and radiological outcomes have, 
however, not been studied in large cohorts and nor has the incidence of cardiomyopathy or its' impact on survival.

In a previous study on the natural history of Leigh syndrome, we included 130 patients, of whom 77 had genetic diagnosis at the time of publication.[21] Since then, more of these patients have been clarified genetically allowing us to study associations between the genotypes and associated clinical outcomes. The aims of this study were (a) to identify phenotypic features that may differentiate between mitochondrial DNA (mtDNA) and nuclear DNA (nDNA) associated Leigh syndrome and (b) to study distinct phenotypes and overlapping phenotypic features across the different genetic subgroups. In order to address these research questions, we studied patients' clinical characteristics, biochemical findings, neuroimaging data and disease outcomes across the different genetic subgroups. Our findings suggest a strong association between certain genetic defects and the phenotype and disease outcome of Leigh syndrome.

\section{METHODS}

\section{Study design and population}

The present study is part of a large cohort study performed within the Mitochondrial Clinical and Research Network (MCRN). The study was conducted at 8 European centers in Gothenburg, Rotterdam, Helsinki, Copenhagen, Stockholm, Brussels, Bergen and Oulu. These are national expert/reference centers specializing in mitochondrial diseases. We included patients with Leigh syndrome who were diagnosed and followed at the participating centers and fulfilled the inclusion criteria: (i) clinical features compatible with Leigh syndrome, e.g. psychomotor regression, dystonia, ataxia and/or brainstem dysfunction and (ii) MRI or CT or neuropathological findings of Leigh syndrome, as follows: bilateral symmetrical lesions in the basal ganglia, and/or thalamus, and/or brainstem. Patients were excluded from the study if they had known mitochondrial phenotypes other than Leigh syndrome. Patient data were collected with the help of electronic data capture. The methodology along with longitudinal natural history data on the overall study population of 130 patients are described elsewhere.[21] 
We used whole exome sequencing either alone or after targeted sequencing or gene-panel sequencing failed to identify the cause. While ours was not a population-based study, the results reflect the genetic diversity found in these areas of Europe.

Muscle pathology suggestive of mitochondrial myopathy was considered with any one of the following findings: mitochondrial proliferation or structurally abnormal mitochondrial on light and/or electron microscopy, ragged red fibers, abnormal oxidative staining (i.e. cytochrome oxidase -COX; succinate dehydrogenase -SDH; nicotinamide adenine dinucleotide reductase $\mathrm{NADH}$; Mg-ATPase). The following muscle findings were considered non-specific: fiber atrophy (type I or II or combined), infiltration of macrophages or T-cells and lipid accumulation.

\section{Statistical considerations}

The statistical evaluations performed were mainly exploratory. Survival outcomes were estimated with the help of Kaplan-Meier analysis. Chi-square test was used to test the association between categorical variables. All statistical tests were two-sided and performed at a 0.05 significance level.

\section{Ethical considerations}

The study was approved by the local ethical committee of each participating center, as per the standing regulatory requirements.

\section{RESULTS}

Here we present the results from 96 patients with genetically verified Leigh syndrome. The geographic distribution and genetic variability of our patients is depicted in Figure 1. 65 patients had Leigh syndrome caused by mutations in nuclear genes, while 31 patients had mtDNA associated disease. Most patients were of Caucasian origin (68/96).

\section{nDNA associated Leigh syndrome}

We studied 65 patients (43 males; 22 females) with Leigh syndrome due to nDNA mutations. The median age of onset was 5 months (range: intrauterine - 10.6 years). Hypotonia was the most common feature of nDNA associated Leigh syndrome (55/65), followed by dyskinesia (40/65) and hypertonia and/or spasticity (34/65). Ataxia was less common (16/65). Ocular involvement was seen in more than half of these patients (35/65), including nystagmus (15), 
optic atrophy (13), strabismus (11), visual impairment (9), ophthalmoplegia (7), retinopathy (5), saccadic eye movement (2), abnormal pupillary reflex (2) and diplopia (1). Eleven patients developed heart disease, as follows: cardiomyopathy (5), arrhythmias (3), heart valve disease (2) and conduction defect (1). Sensorineural hearing loss was common (18/65), mainly in patients with defects in SUCLA2, SUCLG1 and SERAC1.

Eight distinct genetic subgroups were identified, as shown in Table 1. Six patients did not fit into any of these subgroups. They had the following genetic defects: BCSIL (1/6); c12orf65 (1/6); ECHS1 (1/6); ETHE1 (1/6); PNPTI (1/6) and TSFM (1/6). 
Table 1. Genetic subgroups and associated phenotypes of patients with Leigh syndrome $(n=96)$

\begin{tabular}{|c|c|c|c|c|c|c|c|c|c|c|c|c|c|c|c|c|c|c|c|}
\hline \multirow{2}{*}{$\begin{array}{l}\text { Genetic } \\
\text { subgrou } \\
\text { p (n) }\end{array}$} & \multirow[b]{2}{*}{$\begin{array}{l}\text { Medi } \\
\text { an } \\
\text { age } \\
\text { of } \\
\text { onset }\end{array}$} & \multicolumn{9}{|c|}{ Clinical features } & \multirow[b]{2}{*}{$\begin{array}{l}\text { Abnorm } \\
\text { al } \\
\text { lactate } \\
\text { in b } \\
\text { and/or } \\
\text { CSF }\end{array}$} & \multirow[b]{2}{*}{$\begin{array}{l}\text { Respiratory } \\
\text { chain } \\
\text { complex } \\
\text { deficiency/- } \\
\text { ies }\end{array}$} & \multirow[b]{2}{*}{$\begin{array}{l}\text { Mito- } \\
\text { chondrial } \\
\text { myopathy } \\
\text { on muscle } \\
\text { biopsy\# }\end{array}$} & \multicolumn{6}{|c|}{ Neuroimaging } \\
\hline & & $\begin{array}{l}\text { Hypo } \\
\text { tonia }\end{array}$ & $\begin{array}{l}\text { Hyperto } \\
\text { nia } \\
\text { and/or } \\
\text { spasticit } \\
\text { y }\end{array}$ & $\begin{array}{l}\text { Ataxi } \\
\text { a }\end{array}$ & $\begin{array}{l}\text { Dysk } \\
\text { inesi } \\
\text { a }\end{array}$ & $\begin{array}{l}\text { Seiz } \\
\text { ures }\end{array}$ & $\begin{array}{l}\text { Ocular } \\
\text { (ophthalm } \\
\text { oplegia) }\end{array}$ & $\begin{array}{l}\text { Car } \\
\text { diac }\end{array}$ & $\begin{array}{l}\text { Resp } \\
\text { irator } \\
y\end{array}$ & $\begin{array}{l}\mathrm{Re} \\
\text { nal }\end{array}$ & & & & $\begin{array}{l}\text { Basal } \\
\text { gangli } \\
\text { a }\end{array}$ & $\begin{array}{l}\text { Thala } \\
\text { mi }\end{array}$ & $\begin{array}{l}\text { Brain } \\
\text { stem }\end{array}$ & $\begin{array}{l}\text { Cere } \\
\text { bellu } \\
\mathrm{m}\end{array}$ & $\begin{array}{l}\text { SW } \\
\text { M }\end{array}$ & $\begin{array}{l}\text { Cere } \\
\text { bral } \\
\text { corte } \\
\mathrm{x}\end{array}$ \\
\hline $\begin{array}{l}M T-N D \\
(\mathrm{n}=12)\end{array}$ & $\begin{array}{l}11.5 \\
\mathrm{~m}\end{array}$ & 7 & 11 & 8 & 6 & 3 & $9(6)$ & 4 & 5 & 0 & 11 of 12 & 9 of $12\left(\mathrm{CI}^{*}\right)$ & 3 of 12 & $\begin{array}{l}9 \text { of } \\
11\end{array}$ & $\begin{array}{l}5 \text { of } \\
11\end{array}$ & $\begin{array}{l}9 \text { of } \\
11\end{array}$ & $\begin{array}{l}2 \text { of } \\
11\end{array}$ & $\begin{array}{l}3 \text { of } \\
11\end{array}$ & $\begin{array}{l}1 \text { of } \\
11\end{array}$ \\
\hline $\begin{array}{l}M T- \\
A T P 6 \\
(\mathrm{n}=17)\end{array}$ & $6 m$ & 11 & 6 & 9 & 10 & 5 & $11(2)$ & 2 & 8 & 0 & 13 of 17 & $\begin{array}{l}9 \text { of } 14 \\
\text { (variable) }\end{array}$ & 4 of 14 & $\begin{array}{l}\$ 15 \text { of } \\
17\end{array}$ & $\begin{array}{l}2 \text { of } \\
17\end{array}$ & $\begin{array}{l}7 \text { of } \\
17\end{array}$ & $\begin{array}{l}7 \text { of } \\
17\end{array}$ & $\begin{array}{l}4 \text { of } \\
17\end{array}$ & $\begin{array}{l}2 \text { of } \\
17\end{array}$ \\
\hline $\begin{array}{l}M T- \\
t R N A * * \\
(\mathrm{n}=2)\end{array}$ & $\begin{array}{l}1 \mathrm{y} 4 \\
\mathrm{~m}\end{array}$ & 1 & 2 & 0 & 0 & 1 & $2(0)$ & 1 & 2 & 0 & 2 of 2 & $\begin{array}{l}2 \text { of } 2 \\
(\mathrm{CI}+\mathrm{CIV})\end{array}$ & 2 of 2 & 1 of 2 & 1 of 2 & $\begin{array}{l}1 \text { of } \\
2\end{array}$ & $\begin{array}{l}1 \text { of } \\
2\end{array}$ & $\begin{array}{l}2 \text { of } \\
2\end{array}$ & $\begin{array}{l}1 \text { of } \\
2\end{array}$ \\
\hline $\begin{array}{l}N D U F \\
(\mathrm{n}=12)\end{array}$ & $4.5 \mathrm{~m}$ & 11 & 8 & 0 & 8 & 7 & $10(1)$ & 6 & 6 & 4 & 9 of 12 & $\begin{array}{l}12 \text { of } 12 \\
(\mathrm{CI} * * *)\end{array}$ & 2 of 12 & $\begin{array}{l}10 \text { of } \\
12\end{array}$ & $\begin{array}{l}5 \text { of } \\
12 \\
\end{array}$ & $\begin{array}{l}8 \text { of } \\
12 \\
\end{array}$ & $\begin{array}{l}3 \text { of } \\
12\end{array}$ & $\begin{array}{l}4 \text { of } \\
12 \\
\end{array}$ & $\begin{array}{l}7 \text { of } \\
12 \\
\end{array}$ \\
\hline $\begin{array}{l}\text { SURFI } \\
(\mathrm{n}=8)\end{array}$ & $6.5 \mathrm{~m}$ & 8 & 3 & 5 & 3 & 3 & $5(1)$ & 1 & 4 & 0 & 6 of 6 & 8 of 8 (CIV) & 5 of 7 & 7 of 7 & 1 of 7 & $\begin{array}{l}6 \text { of } \\
7\end{array}$ & $\begin{array}{l}1 \text { of } \\
7\end{array}$ & $\begin{array}{l}2 \text { of } \\
7\end{array}$ & $\begin{array}{l}1 \text { of } \\
7\end{array}$ \\
\hline $\begin{array}{l}S L C 19 A 3 \\
(\mathrm{n}=12)\end{array}$ & $1.5 \mathrm{~m}$ & 8 & 12 & 2 & 5 & 10 & $5(1)$ & 0 & 9 & 0 & 8 of 10 & 2 of 8 (CIV) & 2 of 7 & $\begin{array}{l}10 \text { of } \\
11\end{array}$ & $\begin{array}{l}10 \text { of } \\
11\end{array}$ & $\begin{array}{l}4 \text { of } \\
11\end{array}$ & $\begin{array}{l}5 \text { of } \\
11\end{array}$ & $\begin{array}{l}1 \text { of } \\
11\end{array}$ & $\begin{array}{l}3 \text { of } \\
11\end{array}$ \\
\hline $\begin{array}{l}\text { PDHAI } \\
(\mathrm{n}=6)\end{array}$ & $9 \mathrm{~m}$ & 6 & 1 & 3 & 1 & 0 & $3(0)$ & 0 & 2 & 0 & 5 of 5 & $\begin{array}{l}2 \text { of } 4 \\
\text { (variable) }\end{array}$ & 0 of 4 & 5 of 6 & 0 of 6 & $\begin{array}{l}1 \text { of } \\
6\end{array}$ & $\begin{array}{l}2 \text { of } \\
6\end{array}$ & $\begin{array}{l}1 \text { of } \\
6\end{array}$ & $\begin{array}{l}1 \text { of } \\
6\end{array}$ \\
\hline $\begin{array}{l}\text { SERACI } \\
(\mathrm{n}=5)\end{array}$ & $\begin{array}{l}\text { perin } \\
\text { atal }\end{array}$ & 5 & 5 & 2 & 5 & 4 & $4(1)$ & 1 & 1 & 0 & 5 of 5 & $\begin{array}{l}2 \text { of } 5 \\
\text { (variable) }\end{array}$ & 2 of 5 & 5 of 5 & 0 of 5 & $\begin{array}{l}1 \text { of } \\
5\end{array}$ & $\begin{array}{l}3 \text { of } \\
5\end{array}$ & $\begin{array}{l}2 \text { of } \\
5\end{array}$ & $\begin{array}{l}0 \text { of } \\
5\end{array}$ \\
\hline $\begin{array}{l}\text { SUCLA2 } \\
(\mathrm{n}=11)\end{array}$ & $2 \mathrm{~m}$ & 11 & 0 & 2 & 11 & 3 & $2(0)$ & 0 & 2 & 0 & 8 of 10 & $\begin{array}{l}5 \text { of } 6 \\
\text { (variable) }\end{array}$ & 1 of 5 & $\begin{array}{l}11 \text { of } \\
11\end{array}$ & $\begin{array}{l}0 \text { of } \\
11\end{array}$ & $\begin{array}{l}0 \text { of } \\
11\end{array}$ & $\begin{array}{l}0 \text { of } \\
11\end{array}$ & $\begin{array}{l}2 \text { of } \\
11\end{array}$ & $\begin{array}{l}1 \text { of } \\
11\end{array}$ \\
\hline $\begin{array}{l}\text { SUCLGI } \\
(\mathrm{n}=2)\end{array}$ & $5 \mathrm{~m}$ & 2 & 1 & 0 & 2 & 0 & $1(0)$ & 1 & 0 & 0 & 2 of 2 & $\begin{array}{l}2 \text { of } 2 \\
\text { (variable) }\end{array}$ & 0 of 2 & 2 of 2 & 0 of 2 & $\begin{array}{l}0 \text { of } \\
2\end{array}$ & $\begin{array}{l}0 \text { of } \\
2\end{array}$ & $\begin{array}{l}2 \text { of } \\
2\end{array}$ & $\begin{array}{l}0 \text { of } \\
2\end{array}$ \\
\hline $\begin{array}{l}\text { MTFMT } \\
(\mathrm{n}=3)\end{array}$ & $\begin{array}{l}8 \mathrm{y} 2 \\
\mathrm{~m}\end{array}$ & 2 & 3 & 0 & 2 & 0 & $1(0)$ & 0 & 1 & 0 & 2 of 3 & $\begin{array}{l}2 \text { of } 3 \\
\text { (variable) }\end{array}$ & 1 of 3 & 3 of 3 & 0 of 3 & $\begin{array}{l}1 \text { of } \\
3\end{array}$ & $\begin{array}{l}2 \text { of } \\
3 \\
\end{array}$ & $\begin{array}{l}0 \text { of } \\
3\end{array}$ & $\begin{array}{l}0 \text { of } \\
3 \\
\end{array}$ \\
\hline $\begin{array}{l}\text { Other*** } \\
*(\mathrm{n}=6)\end{array}$ & $7.5 \mathrm{~m}$ & 4 & 2 & 2 & 3 & 1 & $4(3)$ & 2 & 0 & 0 & 5 of 5 & $\begin{array}{l}4 \text { of } 5 \\
\text { (variable) }\end{array}$ & 3 of 5 & 4 of 6 & 3 of 6 & $\begin{array}{l}2 \text { of } \\
6\end{array}$ & $\begin{array}{l}0 \text { of } \\
6\end{array}$ & $\begin{array}{l}2 \text { of } \\
6\end{array}$ & $\begin{array}{l}0 \text { of } \\
6\end{array}$ \\
\hline $\begin{array}{l}\mathrm{b}=\text { blood; } \\
\text { CI=Compl } \\
\text { \#Mitochon } \\
\text { COX; succ } \\
\text { § Only CT } \\
\text { * All } 9 \text { pat } \\
\text { ** Patients } \\
* * * \text { All } 12 \\
* * * * \text { Patien }\end{array}$ & $\begin{array}{l}\text { vailable } \\
\text { nts had } \\
\text { lad defe } \\
\text { atients }\end{array}$ & $\begin{array}{l}\text { ydrogen } \\
\text { in } 3 \text { pat } \\
\text { CI defic } \\
\text { cts in th } \\
\text { lad CI d } \\
\text { ects in }\end{array}$ & $\begin{array}{l}\text { ents with m } \\
\text { following } \\
\text { ficiency, } 3\end{array}$ & $\begin{array}{l}\text { utations } \\
\text { nem con } \\
\text { MT-tRN } \\
\text { of them }\end{array}$ & $\begin{array}{l}\text { ide ade } \\
\text { in } M T- \\
\text { bined } \\
\text { A genes } \\
\text { combin }\end{array}$ & $\begin{array}{l}\text { ine din } \\
T P 6 \\
\text { th CII } \\
M T-T \\
\text { d with }\end{array}$ & $\begin{array}{l}\text { CIV or CV } \\
(1 / 2) \text { and } N \\
\text { III or CIII de }\end{array}$ & $\begin{array}{l}\text { eficier } \\
T-T L 1, \\
\text { icienc } \\
F C H S\end{array}$ & $\begin{array}{l}\text { Matter } \\
\text { V; CI-I }\end{array}$ & $=\mathrm{Cor}$ & plex I to IV & & . & & & & & & \\
\hline
\end{tabular}


Mitochondrial changes on muscle biopsy were found in the majority of patients with SURF1 defects (5/7), including COX deficiency (4/7) and mitochondrial proliferation (2/7). Among the other genetic subgroups, mitochondrial abnormalities in muscle were less common (12 patients, Table 1). The group overall muscle pathology findings included COX deficiency (5), SDH deficiency (4), abnormal NADH staining (2), mitochondrial proliferation (1) and structurally abnormal mitochondria on electron microscopy (1).

Mutations in the nuclear-encoded subunits of the NADH:ubiquinone oxidoreductase causing complex I deficiency (NDUF group) were associated with the following distinct phenotypes:

NDUF associated phenotypes $(\mathrm{n}=12)$

The genotypic spectrum involved mutations in the following genes: NDUFS4 (2/12), NDUFS7 (2/12), NDUFV2 (2/12), NDUFAF2 (2/12), NDUFAF5 (2/12), NDUFA9 (1/12) and NDUFA12 (1/12). Four patients were of Caucasian origin, while the remainder were from North Africa and the Middle East. The most common presenting signs were hypotonia (8) and nystagmus (4). Two patients had hypertrophic cardiomyopathy at disease onset, with mutations in NDUFV2 (1) and NDUFS4 (1) genes.

The disease course was characterized by hypotonia (11), hypertonia or spasticity (8) and dystonia (7). In addition to nystagmus (6), patients developed strabismus (3), optic atrophy (3), visual impairment (3), ophthalmoplegia (1), retinopathy (1) and abnormal saccadic eye movement (1). Intellectual disability was found in all tested patients (7/7) and was severe or profound in 5 of them. Six patients suffered from respiratory complications, mainly central hypoventilation. Six patients developed heart disease, as follows: hypertrophic and/or dilated cardiomyopathy (3/5), mitral valve insufficiency (1/5), pulmonary stenosis (1/5) and conduction defect (1/5). Four patients presented renal abnormalities, including kidney dysplasia (renomegaly (1) and renal aplasia (1)), abnormal renal vein anatomy (1) and renal tubular acidosis (1). These were the only patients in our cohort with renal involvement, underlying that patients with mutations in NDUF genes had significantly higher risk of developing kidney disease or dysplasia $(\mathrm{p}<0.0005)$.

All patients in the NDUF group had complex I deficiency (12/12), 3 in combination with complex II or complex III deficiencies. Two patients had abnormal muscle pathology findings 
suggestive of mitochondrial myopathy, one with enzyme histochemical SDH deficiency and another with combined SDH and COX deficiencies.

Neuroimaging of the brain revealed involvement of the deep grey matter in all patients, with lesions extending to more than one of the deep grey matter structures (9/12) [Table 1 ]. Infratentorial involvement was less common (3/12). The cerebral cortex was affected in 7 patients as follows: frontal, temporal or generalized cortical atrophy (4), T2 signal hyperintensity (2), stroke-like lesions involving the frontal lobe unilaterally (1), and increased lactate signal in the entire cerebrum on spectroscopy (1). The cortical involvement found in the NDUF group was significantly more prevalent compared to the other genetic subgroups $(\mathrm{p}=0.0005)$.

Six patients, with a median age of 18.5 years, were still living while the remaining 6 patients died at a median age of 10.5 months. The latter had mutations in NDUFAF2 (2/6), NDUFA9 (1/6), NDUFS4 (1/6), NDUFS7 (1/6) and NDUFV2 (1/6). They developed multi-system disease with generalized or partial epileptic seizures (5/6), central hypoventilation $(5 / 6)$, heart disease (4/6) and renal involvement (3/6). Increased lactate levels of 4-15 mmol/1 were found in the blood (5/5) and the cerebrospinal fluid (CSF) (2/2).

\section{mtDNA associated Leigh syndrome}

The genotypic and phenotypic features of these 31 patients (18 males; 13 females) grouped into three distinct subgroups, are outlined in Table 1. The median age of onset was 11 months (range: intrauterine - 19 years). In addition to hypotonia, the most common neurologic features were ataxia (17/31) and dyskinesia (16/31). Hypertonia and/or spasticity were less common (11/31). Ophthalmoplegia was found in 8 patients (25.8\%) and 6 patients developed heart disease, cardiomyopathy (5/6) and conduction defect (1/6), respectively. Three patients developed sensorineural hearing loss. Central hypo- and/or hyperventilation was seen in 15 patients, of whom 12 had brainstem lesions on neuroimaging. The brainstem was the second most affected part of the brain (17/30) after the basal ganglia (25/30).

Muscle pathology suggestive of mitochondrial myopathy was found in 9 patients and included the following findings: COX deficiency (3), abnormal SDH staining (2), abnormal NADH staining (2), low Mg-ATPase staining (1), mitochondrial proliferation/ragged red fibers (4), structurally abnormal mitochondrial on electron microscopy (2). 
Two distinct phenotypes caused by two different missense mutations at position $\mathrm{m} .8993$ in the MT-ATP6 gene are described in more detail below.

Mutation m.8993T>G

All 7 patients showed a severe phenotype with onset by 6 months of age. The mutation was homoplasmic or $>90 \%$ heteroplasmic in all patients. Five of 7 patients died by the age of 3 years [Figure 2]. The disease onset was characterized by hypotonia (6/7), muscle weakness (4/7) and failure to thrive (4/7). The patients developed dyskinesia (5/7), central hypoventilation (4/7), nystagmus (3/7) and epilepsy (3/7). Macular atrophy was seen in one patient. All patients had increased lactate levels in blood and CSF. Combined NADH and SDH deficiencies were found on muscle enzyme histochemistry in one patient, while another patient had non-specific findings of infiltration of macrophages and muscle fiber atrophy. Respiratory chain complex deficiencies were found in 4 patients, 2 of them had isolated complex V deficiency and 2 had generally low complex activities. Brain MRI (6/7) showed T2 signal hyperintensity and/or atrophy of the basal ganglia (5/6), midbrain (3/6), cerebellum (3/6), supratentorial white matter (2/6) and cerebral cortex (1/6).

Mutation m.8993T >C

As opposed to the severe phenotype of $\mathrm{m} .8993 \mathrm{~T}>\mathrm{G}$, all 4 patients with $\mathrm{T}>\mathrm{C}$ mutations had an attenuated phenotype. The mutation was homoplasmic or $>90 \%$ heteroplasmic in all patients. All patients developed symptoms by the age of 1.5 years and all were alive at a median followup of 6.1 years [Figure 2]. The clinical phenotype was characterized by ataxia (4/4), delayed speech development and dysarthria (4/4), diminished deep tendon reflexes (2/4) and retinopathy (2/4). Lactate levels were normal in blood (4/4) and slightly increased in CSF (2/4). Muscle fiber degeneration was found on biopsy in one patient. Two patients had normal respiratory chain enzyme activities, one had isolated complex $\mathrm{V}$ deficiency and another had generally low complex activities. Brain neuroimaging revealed signal changes and/or atrophy restricted to the basal ganglia [Figure 2].

\section{Phenotypic differences and overlaps between mtDNA and nDNA associated Leigh syndrome}


No significant differences were seen in terms of age of onset or disease outcome between these two major groups. Patients with mtDNA mutations were more likely to develop ataxia $(\mathrm{p}=0.004)$, while patients with nDNA mutations were more likely to develop sensorineural hearing loss $(\mathrm{p}=0.046)$. Ophthalmoplegia and cardiomyopathy were more common in the mtDNA compared to the nDNA group without reaching statistical significance $(\mathrm{p}=0.058$ and $\mathrm{p}=0.200$ respectively).

Patients with complex I deficiency due to mutations in either structural or assembly proteins (MT-ND and NDUF subgroups) represented $25 \%$ of our cohort. These patients had significantly higher occurrence of cardiac involvement $(\mathrm{p}=0.001)$ and ocular findings $(\mathrm{p}=0.023)$ compared to the rest of the cohort.

Distinct phenotypic features and phenotypic overlaps across the 7 most common genetic subgroups, i.e. SERAC1, MT-ATP6, MT-ND, NDUF, SURF1, SLC19A3 and SUCLA2, are summarized in Figure 3. Survival outcomes of these genetic subgroups (number of patients, median, min, max) are shown in Figure 4. In addition to the m.8993T $>\mathrm{G}$ associated outcomes described above, poor survival outcomes were found in patients with (a) SLC19A3 mutations who did not receive treatment with thiamine and/or biotin: 8 of 12 patients died at a median age of 1 month, (b) SURF1 mutations: 5 of 8 patients died at a median of 2 years and (c) SERAC1 mutations: 4 of 5 patients died at a median age of 10.5 years.

\section{DISCUSSION}

Our study included 96 patients with genetically confirmed Leigh syndrome diagnosed and followed in 8 centers in Northern and Western Europe. This is, to our knowledge, the largest phenotype-genotype correlation study in Leigh syndrome to be performed on systematically evaluated patients. We identified distinctive as well as overlapping phenotypic features across the genetic subgroups.

We analyzed the different phenotypes caused by missense mutations in the MT-ATP6, m.8993T $>\mathrm{C}$ and $\mathrm{m} .8993 \mathrm{~T}>\mathrm{G}$, and found the following novel correlations: patients with the m.8993T > G mutation had early onset, before 6 months, and poor disease outcome with death by 3 years of age. They also more frequently had epilepsy, failure to thrive, dyskinesia and brainstem dysfunction. Patients with m.8993T $>$ C mutation had later debut, longer survival and 
less severe neurological outcome. Patients with the m.8993T $>$ C mutation showed isolated striatal lesions radiologically, as opposed to lesions in multiple brain areas both supra- and infratentorially found in patients with the $\mathrm{m} .8993 \mathrm{~T}>\mathrm{G}$ mutation.

The percentage of patients with mutations in $M T-N D$ genes was higher in our study compared to previous studies.[14,23] We found that patients with mutations in $M T-N D$ and NDUF genes with complex I deficiency shared clinical features, that differed from the rest of the cohort, such as significantly higher occurrence of cardiac and ocular involvement. These patients also showed similar radiological involvement of multiple deep grey matter structures, often with sparing of the cerebellum. These findings underline the importance of identifying the biochemical defect in oxidative phosphorylation disorders, as similar metabolic phenotypes often lead to similar clinical and radiological phenotypes despite very different genetic mechanisms.

Leigh syndrome is considered to be the most common phenotype among children with mitochondrial disease due to complex I deficiency.[24-26] Other phenotypes include leukoencephalopathy,[27] neonatal cardiomyopathy and encephalopathy,[28,29] and fatal infantile lactic acidosis.[17,25] Our patients with complex I defect presented with a relatively homogeneous phenotype characterized by the early onset of multi-organ disease as has been described in previous studies.[26,30] This was typically characterized by central nervous system, respiratory, ocular, cardiac, auditory and occasionally renal involvement. Furthermore, we found patients with Leigh syndrome due to mutations in NDUF genes to have significantly higher risk of developing kidney disease or dysplasia.

Cardiomyopathy, hypertrophic or dilated, was found in $10 \%$ of our patient cohort and was twice as prevalent in patients with mtDNA mutations compared to the nDNA group. However, in all patients with mtDNA mutations, cardiomyopathy was not present at disease onset but developed later. Two of our patients presented with infantile hypertrophic cardiomyopathy at disease onset. These patients had mutations in NDUFS4 and NDUFA2 confirming previous reports.[18,19] Heart disease alone was not related to poorer survival, neither in the NDUF group, nor in the entire study population, in contrast to previous studies that have correlated heart disease with poorer survival in patients with mitochondrial diseases.[13] 
Our patients with nuclear encoded complex I deficiency had the characteristic symmetrical deep gray matter lesions, but also showed lesions in the cerebral cortex significantly more often than the rest of the cohort. These lesions included cortical atrophy, T2-signal hyperintensities or stroke-like lesions. Radiological involvement of the cortex, commonly reflected by global atrophy, was found in $12 \%$ of patients with Leigh syndrome regardless of genetic cause in one study.[31] Neuropathology studies in Leigh syndrome suggest that the characteristic striatal and brainstem lesions are due to primary energy deprivation.[23] The pathological process causing cortical lesions appears to differ and has been considered as a neurodegenerative process causing neuronal loss and atrophy.[23] The cortical lesions pertaining to either signal changes or strokelike lesions seen in our patients cannot entirely be attributed to secondary neurodegeneration, but suggest a different or complementary pathogenic mechanism. Supratentorial stroke-like lesions in combination with brainstem lesions are commonly seen in mtDNA encoded complex I deficiency.[32] Increased complex I gene expression in the cortex has been seen during cerebral development. This is related to intense neurogenesis, neuronal differentiation and migration.[33] Our findings could thus support the hypothesis that proposes an important role for complex I activity in the neurogenesis and neuroplasticity of specific areas in the human brain; compromised complex I gene expression may therefore lead to primary cortical degeneration.[34]

The prognosis of Leigh syndrome due to nuclear encoded complex I deficiency is poor, especially in patients with core subunit mutations. Thus far no clear association between the prognosis and the underlying genetic, neuroimaging, or biochemical defects exists.[24,26] Our studied patients had variable lifespan from early death to survival beyond the fifth decade. Early onset is associated with poorer survival, but this is true for Leigh syndrome regardless of the genetic cause.[21,25] In addition, patients in our study who died at preschool age shared the clinical features of early onset multi-system disease with epileptic seizures, central hypoventilation, cardiac and renal involvement.

Muscle histopathology is an important diagnostic tool in suspected mitochondrial disease, along with respiratory chain enzyme activities. Specific myopathic findings are linked to specific 
mitochondrial myopathies and to certain mtDNA defects in particular.[35] In our study, the only genetic subgroup with consistently abnormal histopathologic findings on muscle biopsy was the SURF1 subgroup showing COX deficiency and mitochondrial proliferation as described in the literature.[36] In the total cohort, only $32 \%$ of patients with either mtDNA or nDNA associated Leigh syndrome had histopathological findings in muscle suggestive of mitochondrial disease. Furthermore, $27 \%$ of our cohort had normal respiratory chain enzyme activities, and $15 \%$ had normal lactate levels in both blood and CSF. Patients with mutations in the NDUF genes showed combined complex deficiencies. This has been previously shown with mutations in complex I subunit genes (either mtDNA or nDNA) and attributed to disruption of the respiratory chain supercomplexes by the truncated complex.[37,38]

Our study describes the largest cohort of Leigh disease to date and adds considerably to existing knowledge concerning phenotype-genotype associations. We provide new insights into the phenotypic panorama of certain genotypes considered to be common causes of Leigh syndrome, e.g. mutations in the MT-ATP6 and NDUF genes. Further, we have identified important phenotypic differences between mtDNA- and nDNA-associated Leigh syndrome and showed that diagnosis usually requires the combination of different investigations, such as laboratory and genetic testing, in addition to thorough clinical and radiological evaluation. The discovery of new genetic causes makes phenotype-genotype correlations difficult and the diagnosis of Leigh disease challenging. Studies such as ours are important therefore to improve recognition of this disease, understanding its outcome and to ensure that potential treatments can be properly evaluated.

COMPETING INTERESTS: None declared.

\section{REFERENCES}

1. Darin N, Oldfors A, Moslemi AR, Holme E, Tulinius M. The incidence of mitochondrial encephalomyopathies in childhood: clinical features and morphological, biochemical, and DNA anbormalities. Ann Neurol 2001;49(3):377-83. 
2. Rahman S, Blok RB, Dahl HH, Danks DM, Kirby DM, Chow CW, Christodoulou J, Thorburn DR. Leigh syndrome: clinical features and biochemical and DNA abnormalities. Ann Neurol 1996;39:343-51.

3. Lake NJ, Compton AG, Rahman S, Thorburn DR. Leigh syndrome: One disorder, more than 75 monogenic causes. Ann Neurol 2016;79(2):190-203.

4. Thorburn DR, Rahman S. In: GeneReviews ${ }^{\circledR}$ [Internet]. Seattle (WA) Pagon RA, Adam MP, Ardinger HH, Wallace SE, Amemiya A, Bean LJH, Bird TD, Ledbetter N, Mefford HC, Smith RJH, Stephens K, editors. Seattle: University of Washington; Mitochondrial DNA-Associated Leigh Syndrome and NARP. 1993-2017

5. Gerards M, Sallevelt SC, Smeets HJ. Leigh syndrome: Resolving the clinical and genetic heterogeneity paves the way for treatment options. Mol Genet Metab 2016;117(3):30012.

6. Moslemi AR, Tulinius M, Darin N, Aman P, Holme E, Oldfors A. SURF1 gene mutations in three cases with Leigh syndrome and cytochrome c oxidase deficiency. Neurology 2003;61(7):991-3.

7. Carrozzo R, Verrigni D, Rasmussen M, de Coo R, Amartino H, Bianchi M, Buhas D, Mesli S, Naess K, Born AP, Woldseth B, Prontera P, Batbayli M, Ravn K, Joensen F, Cordelli DM, Santorelli FM, Tulinius M, Darin N, Duno M, Jouvencel P, Burlina A, Stangoni G, Bertini E, Redonnet-Vernhet I, Wibrand F, Dionisi-Vici C, Uusimaa J, Vieira P, Osorio AN, McFarland R, Taylor RW, Holme E, Ostergaard E. Succinate-CoA ligase deficiency due to mutations in SUCLA2 and SUCLG1: phenotype and genotype correlations in 71 patients. J Inherit Metab Dis 2016;39(2):243-52.

8. Ostergaard E, Hansen FJ, Sorensen N, Duno M, Vissing J, Larsen PL, Faeroe O, Thorgrimsson S, Wibrand F, Christensen E, Schwartz M. Mitochondrial encephalomyopathy with elevated methylmalonic acid is caused by SUCLA2 mutations. Brain 2007;130(3):853-61.

9. Ortigoza-Escobar JD, Molero-Luis M, Arias A, Oyarzabal A, Darín N, Serrano M, Garcia-Cazorla A, Tondo M, Hernández M, Garcia-Villoria J, Casado M, Gort L, Mayr JA, Rodríguez-Pombo P, Ribes A, Artuch R, Pérez-Dueñas B. Free-thiamine is a potential biomarker of thiamine transporter-2 deficiency: a treatable cause of Leigh syndrome. Brain 2016;139(Pt 1):31-8. 
10. Ozand PT, Gascon GG, Al Essa M, Joshi S, Al Jishi E, Bakheet S, Al Watban J, Al-Kawi MZ, Dabbagh O. Biotin-responsive basal ganglia disease: a novel entity. Brain 1998;121(7):1267-79.

11. Ruhoy IS, Saneto RP. The genetics of Leigh syndrome and its implications for clinical practice and risk management. Appl Clin Genet 2014;7:221-34.

12. Debray FG, Lambert M, Lortie A, Vanasse M, Mitchell GA. Long-term outcome of Leigh syndrome caused by the NARP-T8993C mtDNA mutation. Am J Med Genet A 2007;143A(17):2046-51.

13. Holmgren D, Wåhlander H, Eriksson BO, Oldfors A, Holme E, Tulinius M. Cardiomyopathy in children with mitochondrial disease; clinical course and cardiological findings. Eur Heart J. 2003;24(3):280-8.

14. Scaglia F, Towbin JA, Craigen WJ, Belmont JW, Smith EO, Neish SR, Ware SM, Hunter JV, Fernbach SD, Vladutiu GD, Wong LJ, Vogel H. Clinical spectrum, morbidity, and mortality in 113 pediatric patients with mitochondrial disease. Pediatrics. 2004;114(4):925-31.

15. Loeffen J, Elpeleg O, Smeitink J, Smeets R, Stockler-Ipsiroglu S, Mandel H, Sengers R, Trijbels F, van den Heuvel L. Mutations in the complex I NDUFS2 gene of patients with cardiomyopathy and encephalomyopathy. Ann Neurol 2001;49:195-201.

16. Bénit P, Beugnot R, Chretien D, Giurgea I, De Lonlay-Debeney P, Issartel JP, CorralDebrinski M, Kerscher S, Rustin P, Rötig A, Munnich A. Mutant NDUFV2 subunit of mitochondrial complex I causes early onset hypertrophic cardiomyopathy and encephalopathy. Hum Mutat 2003;21(6):582-6.

17. Berger I, Hershkovitz E, Shaag A, Edvardson S, Saada A, Elpeleg O. Mitochondrial complex I deficiency caused by a deleterious NDUFA11 mutation. Ann Neurol 2008;63(3):405-8.

18. Petruzzella V, Vergari R, Puzziferri I, Boffoli D, Lamantea E, Zeviani M, Papa S. A nonsense mutation in the NDUFS4 gene encoding the $18 \mathrm{kDa}$ (AQDQ) subunit of complex I abolishes assembly and activity of the complex in a patient with Leigh-like syndrome. Hum Molec Genet 2001;10(5):529-35. 
19. Hoefs SJ, Dieteren CE, Distelmaier F, Janssen RJ, Epplen A, Swarts HG, Forkink M, Rodenburg RJ, Nijtmans LG, Willems PH, Smeitink JA, van den Heuvel LP. NDUFA2 complex I mutation leads to Leigh disease. Am J Hum Genet 2008;82(6):1306-15.

20. Collet M, Assouline Z, Bonnet D, Rio M, Iserin F, Sidi D, Goldenberg A, Lardennois C, Metodiev MD, Haberberger B, Haack T, Munnich A, Prokisch H, Rötig A. High incidence and variable clinical outcome of cardiac hypertrophy due to ACAD9 mutations in childhood. Eur J Hum Genet 2016;24(8):1112-6.

21. Sofou K, De Coo IF, Isohanni P, Ostergaard E, Naess K, De Meirleir L, Tzoulis C, Uusimaa J, De Angst IB, Lönnqvist T, Pihko H, Mankinen K, Bindoff LA, Tulinius M, Darin N. A multicenter study on Leigh syndrome: disease course and predictors of survival. Orphanet J Rare Dis 2014;9:52.

22. Ma YY, Wu TF, Liu YP, Wang Q, Song JQ, Li XY, Shi XY, Zhang WN, Zhao M, Hu LY, Yang YL, Zou LP. Genetic and biochemical findings in Chinese children with Leigh syndrome. J Clin Neurosci 2013;20(11):1591-4.

23. Lake NJ, Bird MJ, Isohanni P, Paetau A. Leigh syndrome: neuropathology and pathogenesis. J Neuropathol Exp Neurol 2015;74(6):482-92.

24. Distelmaier F, Koopman WJ, van den Heuvel LP et al. Mitochondrial complex I deficiency: from organelle dysfunction to clinical disease. Brain 2009;132:833-42.

25. Fassone E, Rahman S. Complex I deficiency: clinical features, biochemistry and molecular genetics. J Med Genet 2012;49(9):578-90.

26. Koene S, Rodenburg RJ, van der Knaap MS, Willemsen MA, Sperl W, Laugel V, Ostergaard E, Tarnopolsky M, Martin MA, Nesbitt V, Fletcher J, Edvardson S, Procaccio V, Slama A, van den Heuvel LP, Smeitink JA. Natural disease course and genotypephenotype correlations in Complex I deficiency caused by nuclear gene defects: what we learned from 130 cases. J Inherit Metab Dis 2012;35(5):737-47.

27. Björkman K, Sofou K, Darin N, Holme E, Kollberg G, Asin-Cayuela J, Holmberg Dahle KM, Oldfors A, Moslemi AR, Tulinius M. Broad phenotypic variability in patients with complex I deficiency due to mutations in NDUFS1 and NDUFV1. Mitochondrion $2015 ; 21: 33-40$. 
28. Bugiani M, Invernizzi F, Alberio S, Briem E, Lamantea E, Carrara F, Moroni I, Farina L, Spada M, Donati MA, Uziel G, Zeviani M. Clinical and molecular findings in children with complex I deficiency. Biochim Biophys Acta 2004;1659(2-3):136-47.

29. Collet M, Assouline Z, Bonnet D, Rio M, Iserin F, Sidi D, Goldenberg A, Lardennois C, Metodiev MD, Haberberger B, Haack T, Munnich A, Prokisch H, Rötig A. High incidence and variable clinical outcome of cardiac hypertrophy due to ACAD9 mutations in childhood. Eur J Hum Genet 2016;24(8):1112-6.

30. Leslie N, Wang X, Peng Y, Valencia CA, Khuchua Z, Hata J, Witte D, Huang T, Bove KE. Neonatal multiorgan failure due to $A C A D 9$ mutation and complex I deficiency with mitochondrial hyperplasia in liver, cardiac myocytes, skeletal muscle, and renal tubules. Hum Pathol 2016;49:27-32.

31. Bonfante E, Koenig MK, Adejumo RB, Perinjelil V, Riascos RF. The neuroimaging of Leigh syndrome: case series and review of the literature. Pediatr Radiol 2016;46(4):44351.

32. Lebre AS, Rio M, Faivre d'Arcier L, Vernerey D, Landrieu P, Slama A, Jardel C, Laforêt P, Rodriguez D, Dorison N, Galanaud D, Chabrol B, Paquis-Flucklinger V, Grévent D, Edvardson S, Steffann J, Funalot B, Villeneuve N, Valayannopoulos V, de Lonlay P, Desguerre I, Brunelle F, Bonnefont JP, Rötig A, Munnich A, Boddaert N. A common pattern of brain MRI imaging in mitochondrial diseases with complex I deficiency. $J$ Med Genet 2011;48(1):16-23.

33. Wirtz S, Schuelke M. Region-Specific expression of mitochondrial complex I genes during murine brain development. PLoS One 2011;6(4):e18897.

34. Ben-Shachar D, Karry R. Neuroanatomical pattern of mitochondrial complex I pathology varies between schizophrenia, bipolar disorder and major depression. PLoS One 2008;3(11):e3676.

35. Kärppä M, Herva R, Moslemi AR, Oldfors A, Kakko S, Majamaa K. Spectrum of myopathic findings in 50 patients with the 3243A>G mutation in mitochondrial DNA. Brain 2005;128(Pt 8):1861-9.

36. Pronicki M, Matyja E, Piekutowska-Abramczuk D, Szymanska-Debinska T, Karkucinska-Wieckowska A, Karczmarewicz E, Grajkowska W, Kmiec T, Popowska E, Sykut-Cegielska J. Light and electron microscopy characteristics of the muscle of 
patients with SURF1 gene mutations associated with Leigh disease. J Clin Pathol 2008;61(4):460-6.

37. Budde SM, van den Heuvel LP, Janssen AJ, Smeets RJ, Buskens CA, DeMeirleir L, Van Coster R, Baethmann M, Voit T, Trijbels JM, Smeitink JA. Combined enzymatic complex I and III deficiency associated with mutations in the nuclear encoded NDUFS4 gene. Biochem Biophys Res Commun. 2000;275(1):63-8.

38. Schägger H, de Coo R, Bauer MF, Hofmann S, Godinot C, Brandt U. Significance of respirasomes for the assembly/stability of human respiratory chain complex I. J Biol Chem. 2004;279(35):36349-53. 


\section{FIGURE LEGENDS}

Figure 1. Patients' geographic distribution and genetic variability $(\mathrm{n}=96)$

Figure 2. Survival analysis and brain MRI of patients with the m.8993T $>\mathrm{C}$ versus the m.8993T $>\mathrm{G}$ associated Leigh syndrome

Figure 3. Distinct phenotypic features and overlaps in the 7 most common genetic subgroups: SERAC1, MT-ATP6, MT-ND, NDUF, SURF1, SLC19A3, SUCLA2

Figure 4. Age (median, min, max) at last follow-up or death for the 7 most common genetic subgroups: SERAC1, MT-ATP6, MT-ND, NDUF, SURF1, SLC19A3, SUCLA2 


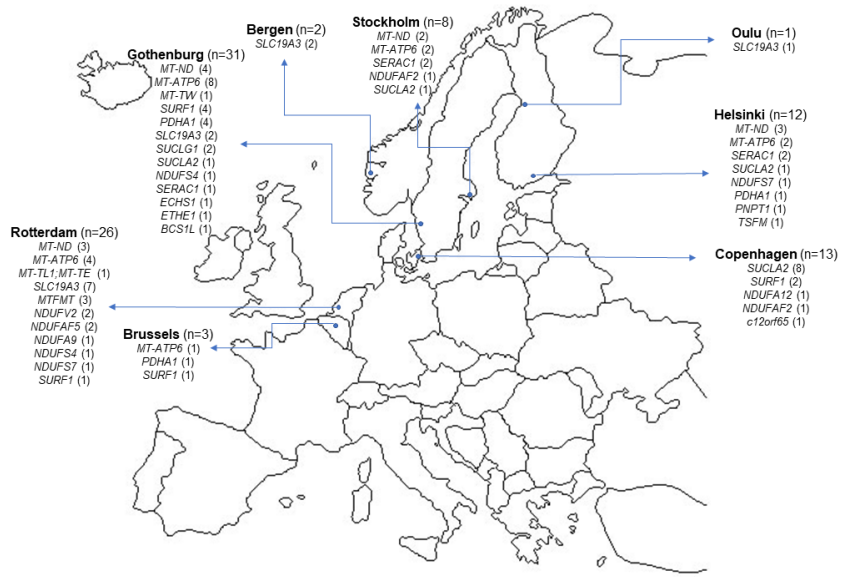


Figure 2.

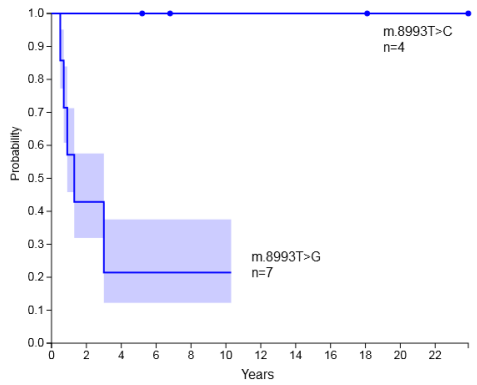

Above: Kaplan-Meier survival curves for the group of patients with m. $8993 \mathrm{~T}>\mathrm{C}$ mutation $(n=4)$ and the m.8993T>G mutation ( $\mathrm{n}=7)$

Right: (a, b) Axial T2 and Sagittal T2 in 1 year old patient with $\mathrm{m} .8993 \mathrm{~T}>\mathrm{G}$ associated Leigh syndrome [1.5 T, TR $2500 \mathrm{~ms}$, TE 70ms]. Signal changes involve the basal ganglia, thalami, midbrain, cerebellum and cerebral cortex. (c, d) Axial T2 and DWl of a 2.5 year old patient with $\mathrm{m} 8993 \mathrm{~T}>\mathrm{C}$ associated Leigh syndrome with signal changes restricted to the putamen bilaterally [1.5 T, TR $3416 \mathrm{~ms}$, TE $88 \mathrm{~ms}$ ].

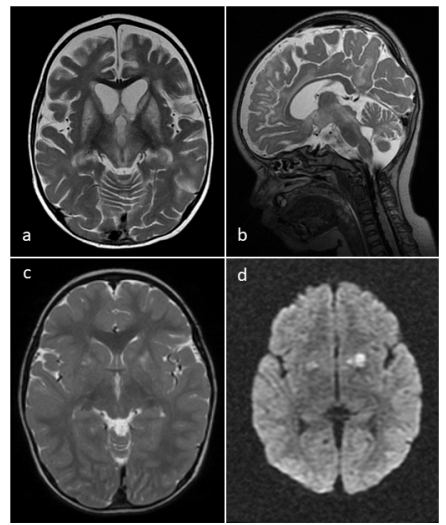


Figure 3.

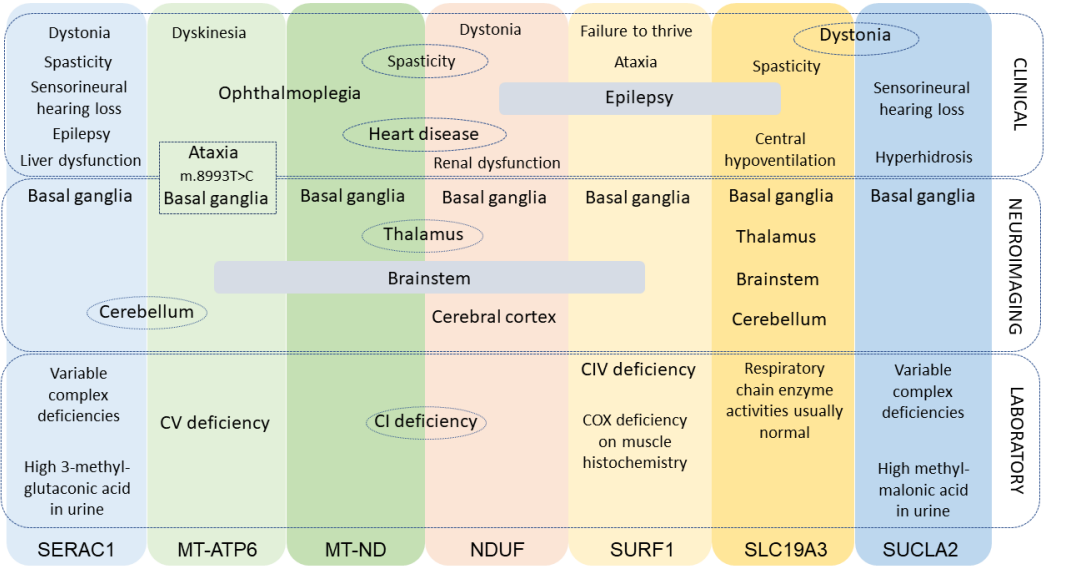


Figure 4.

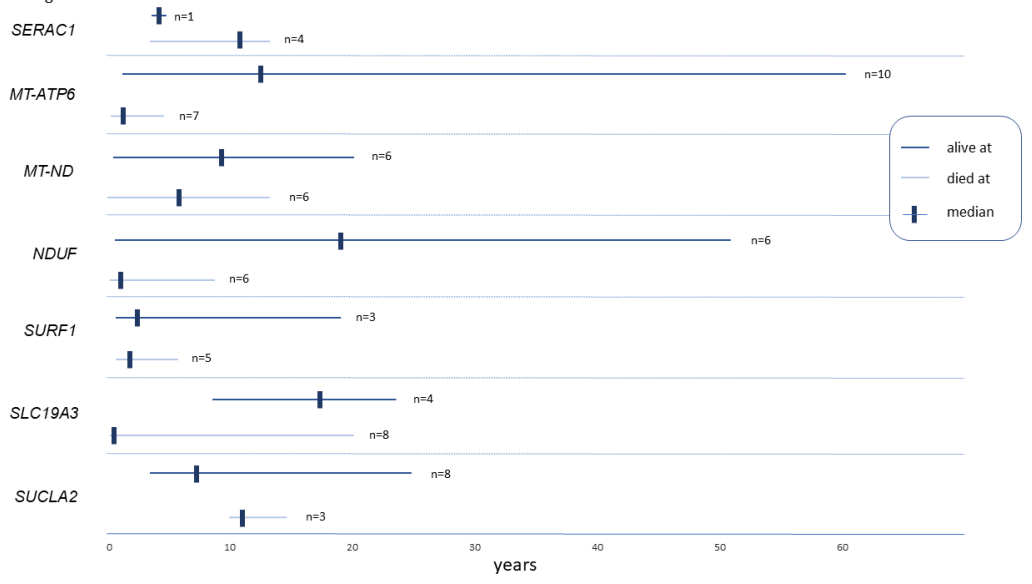

